\title{
Vidners rolle i forebyggelse af mobning: En undersøgelse af det teoretiske og empiriske grundlag for design af vidneinterventioner
}

\section{Eva Gemzøe Mikkelsen}

Ved at gribe ind overfor krænkende handlinger kan vidner medvirke til at forebygge mobning på arbejdspladsen. Forskning viser dog, at vidner til mobning ofte er passive, eller ligefrem støtter udøveren. Dette indikerer et behov for at udvikle interventioner, som får flere vidner til at gribe konstruktivt ind overfor krænkende handlinger. Interventioner bør igen designes og implementeres på basis af empirisk funderet teori, fremfor erfaringsbaserede formodninger. Herværende artikel, som primært er konceptuel teoretisk, udgør et forsøg på at etablere en teoretisk og metodisk forståelsesramme, som forskere og arbejdsmiljøprofessionelle kan anvende som basis for udvikling, implementering og evaluering af interventioner rettet mod vidner til mobning på arbejdspladsen. Bartholomew og Mullens (2011) model over interventionsforskning anvendes til at identificere faser i udviklingen af en vidneintervention samt elementer og processer, som kunne indgå i en sådan. Der præsenteres to teoretiske modeller, O'Reilly og Aquinos (2011) model over tredjeparters reaktioner på oplevet uretfærdighed og Attribution-Emotion Modellen for Stigmatisering (Dijker og Koomen, 2003; Weiner et al., 1988), som beskriver centrale mekanismer involveret i vidneadfærd. Modellernes relevans vurderes tentativt ud fra sekundær empiri, og der identificeres yderligere organisatoriske forhold af betydning for vidners reaktioner på krænkende handlinger. Med udgangspunkt i den præsenterede model og forskning foreslås konkrete elementer og processer, som kan indgå i en vidneintervention.

Nøgleord: Mobning - krænkende handlinger - vidner - forebyggelse - intervention -

\section{Indledning}

Omtrent $11 \%$ af danske arbejdstagere oplever sig udsat for mobning på deres arbejdsplads (NFA, 2018). Mobning kan medføre psykiske og fysiske lidelser som angst, depression, selvmordtanker, diabetes- 2 og hjertekarsygdomme (Mikkelsen et al., 2020) og er derfor en potentielt livstruende stressor.
Som fænomen er mobning karakteriseret ved langvarig og systematisk udsættelse for krænkende handlinger, som de ramte ikke kan forsvare sig imod (Einarsen et al., 2020). At mange mobbede mislykkes i forsøget på at stoppe de krænkende handlinger skyldes i høj grad manglende støtte fra relevante ressourcepersoner, fx ledere, HR eller kolle- 
ger (O'Donnell et al., 2010; Shallcross et al., 2013). I Danmark foregår mobning primært mellem kolleger (Høgh et al., 2009; NFA, 2018). Det første skridt i forebyggelsen af mobning er derfor, at kolleger griber ind overfor krænkende handlinger inden situationen udvikler sig. Forskning viser dog, at vidner til krænkende handlinger ofte er passive eller ligefrem støtter udøveren (Pouwelse et al., 2018). Det indikerer et behov for, at der på arbejdspladsniveau sættes fokus på kollegers rolle i mobning, herunder disses ansvar for at gribe ind, hvis der opstår krænkende handlinger.

På internationalt plan er der begrænset litteratur om, hvordan vidner kan være med til at forebygge mobning på arbejdspladsen. Der mangler også forskningsbaseret viden om, hvilke interventioner, der mest effektivt aktiverer vidner til at gribe ind overfor kolleger, som udøver krænkende handlinger, eller mobber andre kolleger på arbejdspladsen (Desrumeaux et al., 2018). Denne artikel adresserer behovet for at udvikle effektive vidneinterventioner, som kan bruges i en forebyggende indsats mod mobning. Artiklen er primært konceptuel teoretisk og tager udgangspunkt i interventionsdesign-traditionen. Formålet er at etablere en teoretisk og metodisk forståelsesramme, som forskere og arbejdsmiljøprofessionelle kan anvende som basis for at udvikle interventioner, der aktiverer vidner til konstruktiv adfærd i situationer med krænkende handlinger og mobning. Bartholomew og Mullens (2011) model over interventionsforskning anvendes $i$ artiklen til at identificere faser i udviklingen af en vidneintervention samt elementer og processer, som kunne indgå i en sådan. Modellens præmis er, at interventioner rettet mod adfærdsændringer bør være guidet af teori, som kvalificeres gennem empiriske undersøgelser (Bartholomew og Mullen, 2011)

Efter en introduktion til vidnebegrebet og interventionsmodellens første fase, præ- senteres to teoretiske modeller, O'Reilly og Aquinos (2011) model over tredjeparters reaktioner på oplevet uretfærdighed, og Attribution-Emotion Modellen for Stigmatisering (Dijker og Koomen, 2003; Weiner et al., 1988), som beskriver centrale mekanismer involveret i vidneadfærd. Modellernes antagelser og relevans for udviklingen af en vidneintervention vurderes tentativt ud fra bl.a. sekundær empiri. Der beskrives herefter yderligere kontekstforhold relateret til organisationskultur, som også påvirker vidners adfærd og derfor bør inkluderes $i$ en forandringsmodel. Med udgangspunkt i anden fase i Bartholomew og Mullens (2011) model anvendes det udvalgte teoretiske og empiriske fundament til at identificere elementer og sammenhænge, som kan indgå i den forandringsmodel, som skal guide designet af interventionen. Artiklens sidste afsnit indeholder konkrete forslag til elementer og processer, som kunne indgå i en vidneintervention. Der afsluttes med en konklusion og perspektivering.

\section{Vidnebegrebet i relation til mobning på arbejdspladsen}

Mobning på arbejdspladsen har traditionelt være anskuet som et dyadisk fænomen (Wu og Wu, 2019). Med dyadisk menes et perspektiv, der fokuserer på samspillet mellem den eller de personer, som udøver de krænkende handlinger (mobberen/mobberne), og den eller de, som handlingerne går ud over (den mobbede/de mobbede). Dyadens destruktive relation er særligt blevet studeret indenfor to kontekster, arbejdsmiljø og organisationskultur, ligesom forskere også har interesseret sig for, hvad parterne eventuelt har "bragt ind i relationen" (e.g. personforhold som fx personlighed og livssituation, se fx Persson et al., 2018). Hvor forskere i skolemobning tidligt har haft fokus på, hvordan det dynamiske samspil mellem børn kan bidrage til 
og vedligeholde mobning (Twemlow et al., 2004) er kolleger og ledere, der har været vidner til mobning, primært blevet studeret under det anonyme begreb 'social støtte', fx dennes modererende effekt på relationen mellem mobning og individuelle helbredskonsekvenser (se fx Gardner et al., 2013). I de senere år er der dog sket et paradigmeskifte, idet mobning nu italesættes og udforskes bredt som noget, der opstår i triadiske konstellationer (Pouwelse et al., 2018) bestående af de(n) mobbede, mobber(e) og vidner, som interagerer i organisatoriske kontekster med hver sine særlige arbejdsmiljøforhold og kulturelle normfællesskaber.

Vidnerne til mobning er blevet kaldt $\mathrm{Ob}$ servatører (Cooper-Thomas et al., 2014), Vidner (Lewis og Orford, 2005), Kolleger (Tye-Williams og Krone, 2015) og Tilskuere (D'Cruz og Noronha, 2011). Bystanders er den mest benyttede engelsksprogede term (Pouwelse et al., 2018). I Danmark anvendes ordet vidner (Bloch, 2013), hvis betydning adskiller sig fra, hvordan vidnebegrebet bruges i juriske sammenhænge.

Lansbury (2014) definerer et vidne til mobning på arbejdspladsen som

[...]"enhver tilstedevorende tredjepart uanset dennes position, og om vedkommende er en aktiv tilskuer eller en neutral part [...]" (Lansbury, 2014, p. 2, min oversættelse)

I et senere review (Niven et al., 2020), defineres vidner som

[...]"personer som er involveret i nogle af de handlinger, som over tid udgør mobning, enten ved at de selv direkte observerer dem, iagttager dem via teknologi ( $f x$ når de er cc på en e-mail), eller ved at blive informeret om dem" (Niven et al., 2020, p. 386, min oversættelse)
Hvor Lansburys (2014) definition understreger, at vidnet skal være til stede i situationen og giver eksempler på forskellig vidneadfærd, udvider Niven et al. (2020) vidnebegrebet gennem beskrivelse af den tids- og situationelle ramme for vidners tilstedeværelse. Begrebet inkluderer således både vidner til de første krænkende handlinger og til den systematiske mobning. Desuden gives eksempler på proximale og distale måder, man kan være vidne på, fx direkte overværelse af krænkende handlinger, observation af digital mobning, eller gennem information fra andre. Niven og kollegers definition åbner dermed op for langt flere personer, som har mulighed for at gøre noget konstruktivt i situationer med krænkende handlinger og mobning.

Undersøgelser baseret på både de mobbedes og vidners oplevelser af sager om krænkende handlinger og mobning illustrerer kompleksiteten i vidners adfærd, som groft beskrevet kan opdeles i to adfærdsdikotomier; konstruktiv-destruktiv og aktiv-passiv (Niven et al., 2020). Ud fra bl.a. et mixed-method studie identificerer Paull et al., (2012) 13 vidneroller eller positioner: destruktive positioner er fx det Ansporende vidne, der er med til at skabe mobbesituationen, det Samarbejdende vidne, som aktivt hjælper mobberen og det passive, Ansvarsfraloeggende vidne. Modsat indtages konstruktive positioner $\mathrm{fx}$ af det Intervenerende vidne, der griber ind, det Forsvarende vidne, som forsvarer den mobbede, og det Sympatiserende vidne, som kun støtter den mobbede i det skjulte.

En dansk interviewundersøgelse af 17 vidner til kollegamobning (Bloch, 2013) identificerer seks vidnepositioner: Medmobbere (destruktiv-aktiv position), De passive (destruktiv-passiv position), som trækker sig og lægger ansvaret for mobningen over på andre inklusiv den mobbede, Sympatisører (konstruktiv-passiv position), som drøfter handlemuligheder med eller rådgiver den mobbede, 
Forsvarere (konstruktiv-aktiv position), som griber aktivt ind i situationer med mobning, Moeglere (konstruktiv-aktiv position), som $\mathrm{fx}$ tager initiativ til at adressere mobningen efterfølgende, Whistleblowere (konstruktiv-aktiv position), som tager mobningen op med en overordnet ledelsesinstans, og Pendlerne, der er ambivalente overfor den mobbede og skiftevis støtter vedkommende eller mobber med. Blochs pendlergruppe kan genfindes hos Tye-Williams og Krone (2015), der ud fra interviews med mobbede identificerer såkaldte Kamaeleoner - vidner som skiftevis giver støtte, trækker sig eller assisterer mobberen.

De omtalte studier illustrerer et generelt fund i forskningen; at vidner til mobning på arbejdspladsen kan reagere meget forskelligt overfor deres mobbede kolleger, og at den adfærd, det enkelte vidne udviser, kan skifte fra situation til situation. Hvor meget og hvor ofte et vidne skifter position, kan afhænge af, hvilken form for mobning, der er tale om (se Mikkelsen, 2007), og hvordan en given sag udvikler sig. I en konfliktmobningssag ses ofte positionsskift. Et eksempel kan være en kollega, som først støtter den svagere part i en konflikt, men så vælger at trække sig enten fordi de ikke orker mere, eller fordi de frygter repressalier fra en oplevet stærkere kollega eller en leder. Et ekstremt eksempel på konstante positionsskift i "mobningstriaden" findes her i Mortensen og Baarts' (2018) etnografiske feltstudie af humormobning.

Mange sager om mobning starter med sporadiske, lavintensive krænkende handlinger, som kan udvikle sig til alvorlig mobning, hvis ingen intervenerer. Vidner kan potentielt gøre en forskel ved at gribe direkte ind, eller på anden vis støtte personer, der udsættes for krænkende handlinger allerede første gang, disse observeres. Undersøgelser viser, at der er mange vidner, som prøver at hjælpe enten i selve situationen eller efterfølgende (Niven et al., 2020; Wu og Wu, 2019) men også, at mange vidner er passive, eller endda selv mobber med (D'Cruz et al., 2016). Skal vidner spille en aktiv rolle $i$ at forebygge mobning, er det helt afgørende at få en dybere forståelse af, hvorfor vidner reagerer, som de gør. Denne forståelse kan skabe et fundament for designet af interventioner, der kan fremme konstruktiv vidneadfærd i de situationer, hvor der er behov for det.

\section{Design af adfærdsændrende organisatoriske interventioner}

Teori spiller en essentiel rolle i den videnskabelige undersøgelse af, hvordan der kan skabes eller faciliteres adfærdsændringer i bestemte målgrupper. Teorien kan hjælpe med at identificere 'kausale' faktorer bag en given problemadfærd og til at identificere metoder, der fører til ændringer i de forhold, som teorien forudsiger (Bartolomew og Mullen, 2011, s. 21). At 'kausal' sættes i anførselstegn betyder, at der i design, implementering og evaluering af organisatoriske interventioner må tages højde for, at én-til-én årsag-virkningsforhold mellem elementer i en vidneintervention og dens målte effekt ikke nødvendigvis kan etableres. Det sidste skyldes bl.a., at vidners adfærd overfor krænkende handlinger og mobning ofte påvirkes af flere faktorer, ligesom procesforhold kan indvirke på implementeringen og dermed effekten af en intervention (Aust et al., 2010; Mikkelsen et al., 2011).

Som påpeget af bl.a. Bartholomew og Mullen (2011) vil enkelte teorier ofte kun forklare noget af variationen i en given adfærd hos en interventions målgruppe. Forud for designet af interventioner bør eksisterende teorier om årsager til et givent fænomen, og teoriernes empiriske grundlag derfor undersøges og vurderes. I evalueringen af teorier om adfærd og adfærdsændringer bør ideelt anvendes empiri, som har testet sammenhænge mellem specifikke faktorer og en given adfærd eller adfærdsændring. Er der begrænset forskning 
på et område kan til nød anvendes forskning, som har adresseret relaterede fænomener.

Bartholomew og Mullen (2011) foreslår en model for interventionsforskning, hvori teori og empiri spiller en central rolle. Modellen er udviklet inden for forskningen i helbredsrelaterede adfærdsændringer og beskriver med inspiration fra Intervention Mapping metoden (se fx. Meng et al., 2019) fem faser i udviklingen og afprøvningen af interventioner, hvori forskere bør anvende teori: 1) identifikation af adfærd som kan relateres til et aktuelt problem og de faktorer, som er bestemmende herfor; 2) udvikling af en logisk forandringsmodel som inkluderer relevante teoretiske begreber med henblik på at skabe en ønsket adfærdsændring, 3) udvælgelse af interventioner og måder at implementere disse på som inkluderer variable, som ifølge teorien vil mediere relationen mellem interventionens indhold, proces og effekter; 4) evaluering af interventionen inklusiv de variabler, som, i følge teorien, medierer identificerede relationer mellem interventionens indhold og proces og dens effekter, samt; 5) rapportering af interventionens resultater inklusiv de identificerede forandringsfaktorer, der er relateret til interventionerne i sig selv. Fokus for herværende artikel er primært første, sekundært anden og tredje fase i Bartholomew og Mullens (2011) model.

\section{Første fase: Identifikation af forhold, som indvirker på vidners adfærd}

Opgaven i første fase af Bartholomew og Mullens (2011) model er med udgangspunkt i teori og empiri at identificere vidneadfærd relateret til krænkende handlinger og mobning (i.e. kolleger griber ikke ind), og de faktorer, som indvirker herpå. Ifølge Bartholomew og Mullen (2011) kan processen starte med en grundig litteratursøgning for at finde teori og empiri, som identificerer faktorer, der indvir- ker på den problemadfærd, der skal adresseres (i.e. vidnepassivitet og medløben). Aktuelt for denne artikel er identificeret to teoretiske modeller, som beskriver årsager til vidneadfærd: O'Reilly og Aquinos (2011) model over tredjeparters reaktioner på krænkende handlinger og Attribution-Emotion Modellen for Stigmatisering (Dijker og Koomen, 2003; Weiner et al., 1988). De teoretiske modeller er udviklet på basis af henholdsvis empirisk forskning i oplevet uretfærdighed og omgivelsers reaktioner på stigmatiserede personer. Begge har fokus på sammenhængen mellem personers (e.g. vidners) tanker (kognitioner), følelser (emotioner) og adfærd i situationer med stigmatisering og krænkelser, omend centrale antagelser vedrørende disse processer varierer. Modellerne trækkes frem her, da de i litteraturen er fremhævet som bidragende særligt til forståelsen af vidners adfærd overfor mobning på arbejdspladsen (se Pouwelse et al., 2018). Deres hovedantagelser har da også været genstand for empirisk forskning ofte i form af eksperimentelle vignette studier. Et yderligere argument for anvendelsen af de to teoretiske modeller er, at de bygger på forskning i sociale fænomener, der er tæt relaterede til mobning. Systematisk udsættelse for krænkende handlinger vil over tid medføre social stigmatisering (Einarsen et al., 2020). Attribution-Emotion Modellen for Stigmatisering (Dijker og Koomen, 2003; Weiner et al., 1988), der beskriver mentale processer bag omgivelsers prosociale eller asociale adfærd overfor stigmatiserede personer, synes derfor relevant til formålet. O'Reilly og Aquinos (2011) model er udviklet på basis af forskning i oplevet uretfærdighed; et forhold, som er centralt i udviklingen af negativ interpersonlig adfærd som fx konflikter og mobning (Neuman og Baron, 2011; se også Bjørkelo et al., 2018 og Hogh et al., 2017).

I nedenstående afsnit beskrives først O'Reilly og Aquinos teoretiske model, hvorefter dens bidrag til en forklaringsmodel over 
vidneadfærd afprøves tentativt ud fra den omtalte sekundære empiri.

\section{O'Reilly og Aquinos model over reaktioner på kroenkende handlinger}

O'Reilly og Aquinos (2011) model bygger videre på Folgers (2001) Deontiske Retfærdighedsmodel og er bl.a. inspireret af teorier om moralsk intuition, identitetsbaseret motivation (Aquino og Freeman, 2009; Haidt, 2001; refereret i O'Reilly og Aquino, 2011) samt teorier om kognitive og følelsesmæssige reaktioner på uretfærdighed (se fx Neuman og Baron, 2011). Begrebet deontisk retfoerdighed, som er centralt i modellen, henviser til tredjeparters følelsesmæssige reaktioner i situationer, hvor de hører om andre, der er blevet behandlet på en måde, der opleves at krænke moralske normer vedrørende interpersonel adfærd. Ifølge modellen vil et vidne til en uretfærdig handling få en spontan, moralsk intuitiv fornemmelse af, at "Her sker der vist noget uretfoerdigt!". Den intuitive fornemmelse efterfølges af intens moralsk vrede rettet mod den, som udøver uretfærdigheden (O'Reilly og Aquino, 2011). Herefter vil mere bevidste kognitive processer indvirke på vidnets adfærd. Om og hvordan et vidne handler på den moralske vrede, afhænger ifølge teorien af vidnets vurdering af tre forhold: hvor alvorlig handlingen opleves at være, om udøveren kan bebrejdes for sine handlinger, og om den krænkede opleves at fortjene denne behandling. Vurderer vidnet $\mathrm{fx}$, at handlingen er alvorlig, ikke kan retfærdiggøres og at den krænkede behandles uretfærdigt, vil vidnet være motiveret til at straffe krænkeren.

Et centralt element i O'Reilly og Aquinos model er begrebet moralsk identitet. Moralsk identitet er en del af en persons sociale identitet og refererer til i hvor høj grad en persons selvopfattelse er knyttet til det at være en grundlæggende moralsk person (Aquino og Reed, 2002). En persons moralske identitet antages generelt at være stabil og knyttet til moralske træk, som $\mathrm{fx}$ det at være retfærdig, omsorgsfuld og venlig (Aquino og Reed, 2002, s. 1424). Personer, hvis moralske identitet er central for deres selvopfattelse, er mere tilbøjelige til at foretage moralsk baserede vurderinger af en negativ social situation og handle derefter, samt mere tilbøjelige til at opleve moralsk vrede, få negative tanker om udøveren og have lyst til at straffe vedkommende (Aquino og Reed, 2002; O'Reilly og Aquino, 2011). Ved at sætte fokus på individuel moralsk identitet har modellen dermed også et klart individfokus. Ifølge O'Reilly og Aquino (2011) vil vidners reaktioner i en konkret situation dog også afhænge af andre forhold: $\mathrm{fx}$ vidnernes formelle status i relation til udøveren, hvilke ressourcer (fx sociale, netværksmæssige) de har til rådighed $\mathrm{i}$ organisationen, og deres grad af tillid til at organisationen har regler og procedurer, som sikrer en retfærdig sanktion af personer, som krænker andre. Nedenfor behandles kort betydningen af magtforhold for vidneadfærd. Et senere afsnit beskriver organisatoriske forhold, som kan påvirke vidners adfærd i situationer med krænkende handlinger og mobning.

\section{Betydningen af magt for vidners adfoerd overfor krcenkende handlinger}

Magt kan defineres som en persons grad af kontrol over de resultater (outcomes), en anden person kan opnå (Keltner et al., 2003; O'Reilly og Aquino, 2011). Pouwelse et al. (2018) foreslår, at social udvekslingsteori anvendes til at forklare, hvordan magt påvirker vidners adfærd. Teorien antager, at aktører udveksler ressourcer og belønning $\mathrm{i}$ et socialt udvekslingsforhold, hvis dynamik forklares af parternes respektive magt (Blau, 
1964; Emerson, 1962; citeret i Pouwelse et al., 2018, s. 15). Den underlegne part i en dyadisk udvekslingsrelation vil være afhængig af den mere magtfulde part, som kan belønne eller straffe førstnævnte og dermed kontrollere dennes adfærd (Keltner et al., 2003). Omvendt vil personer med mindre magt forsøge at opnå ressourcer fra magtfulde personer ved at tilstræbe en konfliktfri og positiv interaktion med disse (Copeland, 1994). I tråd med dette argumenterer Kiewitz et al. (2016, s. 733) for, at medarbejdere vil føle sig stærkt truet af mobning fra overordnede, hvilket vil motivere undgåelsesorienterede copingstrategier. Mobbede med højere status eller flere ressourcer vil omvendt føle sig mindre truet af mobning, bl.a. fordi et oplevet større handlingsrum fremmer tilnærmelsesrelaterede kognitioner, følelser og adfærd. Hvis teorien anvendes i relation til vidner, antages det, at vidner med lav formel status og begrænsede sociale og netværksmæssige ressourcer vil være mindre tilbøjelige til at gribe ind overfor personer, som qua ressourcer og netværk opleves som mere magtfulde. Omvendt kan vidner med mere formel magt og/eller ressourcemagt end en mobber være mere motiveret til at straffe denne og støtte den mobbede.

\section{Tentativ vurdering af O'Reilly og Aquinos model ud fra sekundaer empiri}

En vurdering af, om O'Reilly og Aquinos model kan anvendes som basis for udviklingen af en vidneintervention, afhænger naturligvis af, om empirisk forskning støtter dens centrale antagelser. Skarlicki og Rupp (2010) fandt fx, at deltagere med stærk moralsk identitet var mere tilbøjelige til at straffe personer, der udøver krænkende handlinger. Hellemans et al. (2017) og Desrumaux et al. (2018) fandt støtte til modellens antagelse om, at vidners vurdering af mobningens alvorlighed indvirker på deres intention om at gribe konstruktivt ind, og at dette kan skyldes en øget sympati for den mobbede (Desrumeaux et al., 2018). Flere undersøgelser med varierende forskningsdesign giver også støtte til antagelsen om, at magt indvirker på vidners adfærd. Interviews med mobbede (Lewis og Orford, 2005; Lutgen-Sandvik og McDermott, 2011) og vidner (Bloch, 2013; D'Cruz og Noronha, 2011) peger på, at vidner er mindre tilbøjelige til at gribe ind overfor overordnede, som mobber. I tråd med dette viser resultater fra to eksperimentelle vignette studier og et feltstudie (Hershcovis et al., 2017), at vidner med lav magt er mere tilbøjelige til at rapportere, at de vil undgå en person, som udviser krænkende adfærd og tilbyde social støtte til den krænkede, mens vidner med mere magt er mere tilbøjelige til at rapportere, at de vil konfrontere krænkeren. Et interessant fund var desuden, at sidstnævnte tilsyneladende er mindre tilbøjelige til at give social og følelsesmæssig støtte til krænkede - med mindre krænkelserne afstedkommer ansvarsfølelser hos vidnet eller opleves som en udfordring af vedkommendes status.

I en kritik af O'Reilly og Aquinos (2011) model, argumenterer Fiori et al. (2016) for, at relationer på en arbejdsplads, fx et venskab mellem to personer, kan påvirke vidners vurderinger, følelser og handlinger i situationer, hvor der sker krænkende eller uretfærdige handlinger. Fiori et al. (2016) introducerer begrebet perspektivtagning, som er det fænomen, hvor mennesker prøver at forstå en anden persons mentale tilstand, følelser, holdninger og vurderinger (Fiori et al., 2016, s. 319). Forskerne argumenterer her for, at vidners reaktioner på afvigende adfærd, fx krænkende handlinger, også afhænger af aktørperspektivet. Resultater fra i alt tre eksperimenter (Fiori et al., 2016) støttede denne antagelse. Vidner, som blev bedt om at tage mobberens perspektiv, var mindre tilbøjelige til at synes, at vedkommende var 
ansvarlig for den krænkende handling, og var derfor også mindre tilbøjelige til at straffe vedkommende.

\section{Attribution-Emotion Modellen for Stigmatisering}

Attribution-Emotion Modellen for Stigmatisering (AEMS) har sit udgangspunkt i teorier om, hvordan mennesker reagerer overfor stigmatiserede individer, fx personer med psykiske eller fysiske sygdomme (Dijker og Koomen, 2003; Weiner et al., 1988). Teorien er anvendt i stor udstrækning i forskningen i stigmatisering, og fokuserer på tredjeparters opfattelse af, hvad den stigmatiserede person gjorde forud for sin stigmatisering, hvilket adresserer kognitive attributionsprocesser. Teorien bygger på forskning, der viser, at negative oplevelser eller begivenheder igangsætter langt flere kognitive processer end positive begivenheder (Baumeister et al., 2001), og at både de, som udsættes for begivenheden og deres omgivelser, forsøger at finde årsagerne til det, der skete (Weiner et al., 1988).

Kernen i AEMS er en kognition-emotion-adfærd sekvens (Pouwelse et al., 2018), som her forklares med reference til en situation med mobning. Vidner vil først søge at forstå eller fortolke hvem, der er skyld i mobningen. Denne attributionsproces er relateret til vidners vurdering af i hvor høj grad den mobbede gennem sin adfærd kan kontrollere det, der sker med vedkommende. Jo mere vidner tænker, at den mobbede selv kan kontrollere det, vedkommende er udsat for, jo mere attribuerer de ansvaret for mobningen til personen. Når vidner har vurderet den mobbedes grad af ansvar for situationen, vil de, ifølge AEMS (Weiner et al., 1998) opleve en af to følelsesmæssige reaktioner, henholdsvis vrede eller sympati. Vredesfølelser vil øge risikoen for, at vidnet udviser antisocial adfærd, altså ikke hjælper den mobbede, mens sympatifølelser omvendt øger sandsynligheden for, at vidnet beslutter at hjælpe. Vidners vurdering af ansvar for en negativ situation (stigmatisering, mobning) vedrører både et vurderet ansvar for, at situationen opstod (perceived onset responsibility, $P O C$ ), og for at den fortsætter (perceived continuation responsibility, PCR) (Pouwelse et al., 2018; Weiner et al., 1988). PCR er relateret til den mobbedes coping, altså hvad vedkommende gør for at håndtere situationen. Anden forskning peger her på, at den måde, personer reagerer på en given stressor og de strategier, de bruger for at håndtere denne, indvirker på den sociale støtte, de modtager (Bolger et al., 1996; Dunkel-Schetter et al., 1987). En forklaring på dette kan være, at mulige støttepersoners følelser og adfærd overfor den ramte person påvirkes af, om de synes, at vedkommende håndterer situationen på den "rigtige" måde, dvs. gør noget aktivt for at stoppe den. Vurderer vidner, at en person coper dårligt fx ved at undgå at forholde sig til situationen, eller ikke gør noget aktivt for at håndtere den, oplever de flere negative følelser, mindre sympati og mindre intention om at hjælpe vedkommende (Bos et al., 2007; Schwarzer og Weiner, 1991).

Dijker og Koomen (2003) har udvidet den oprindelige AEMS-model til også at inkludere det forhold, at stigmatiserede personers omgivelser kan reagere med frygt og angst, hvis de vurderer, at en stigmatisering er selvforskyldt. Frygten skyldes, at de er bange for, at den stigmatiseredes adfærd får negative konsekvenser for dem selv. Ligesom vrede vil frygt ifølge teorien medføre mindre prosocial og mere antisocial vidneadfærd. Med udgangspunkt i Kirby og Corzine (1981) argumenterer Pouwelse et al. (2018) for, at frygt for sygdomssmitte kan paralleliseres med frygten for social smitte. Ud fra teorien kan det antages, at vidner til mobning kan frygte, at den mobbedes uønskede sociale position kan sprede sig til dem selv, hvis de 
associeres med vedkommende. Fænomenet, som Goffman (1963) beskrev som courtesy stigma, kaldes i vidneforskningen og relaterede forskningsområder for stigma by association (Mulder et al., 2014). Ifølge antagelsen om stigma by association kan vidner til mobning tilbageholde støtte til en mobbet person, hvis de frygter, at andre (kolleger, chefer) hermed vil associere dem med vedkommende med negative konsekvenser for dem selv.

\section{Tentativ vurdering af AEMS ud fra sekundoer empiri}

Inden næste fase i udviklingen af en vidneintervention, skal det vurderes, om AEMS bør være en del af fundamentet i den forandringsmodel, der skal styre interventionens design og implementering. Til formålet vurderes tentativt sekundær empiri, som har undersøgt modellen i relation til vidners adfærd overfor krænkende handlinger og mobning. Igen er der tale om empiri baseret primært på et eksperimentelt design, hvori er anvendt vignettes. Resultatet fra en række studier (fx Desrumaux et al., 2015; Hellemans et al., 2017; Hershcovis og Bhatnagar, 2017; Mulder et al., 2016), bekræfter modellens antagelse om, at jo mere vidner mener, at mobning er selvforskyldt, jo flere negative følelser oplever de i relation til den mobbede, hvilket igen fører til, at de har mindre lyst til at hjælpe vedkommende. Støtte til at vidner også påvirkes af, hvordan den mobbedes håndterer situationen, findes i Blochs interviewundersøgelse (2013) og i Mulder et al.'s (2017) vignettestudie; vidner var mere tilbøjelige til at hjælpe mobbede, der aktivt sagde fra overfor mobningen end mobbede, der fx sygemeldte sig. Ligeledes, og i tråd med antagelsen om stigma by association, viser resultater fra vignettestudier (Mulder et al., 2014; Mulder et al., 2016) og interviewundersøgelser i forskellige nationale kontekster (Bloch, 2013; D'Cruz og Noronha,
2011; Lutgen-Sandvik og Fletcher, 2013; Van Heugten, 2011), at vidner kan tilbageholde støtte til mobbede af frygt for eventuelle negative konsekvenser for dem selv.

\section{Metodiske refleksioner over den anvendte sekundcere empiri}

Den empiri, som har undersøgt de beskrevne teoretiske modeller i relation til vidners adfærd i situationer med krænkende adfærd og mobning, har primært anvendt et eksperimentelt vignettedesign. I vignettestudier anvendes korte fiktive cases, eller film, med dertilhørende spørgsmål, som varieres fx hvad angår mobningens alvorlighed og karakterernes respektive magt, intention, eller den adfærd, som de har udvist forud for mobningen (en mobbet beskrives $\mathrm{fx}$ som en uskyldig mønstermedarbejder eller som afviger). Et eksperimentelt design, hvori der anvendes vignettes eller film, er som udgangspunkt velegnet til at besvare forskningsspørgsmål, der vedrører følsomme emner (Torres, 2009). Ved manipulering af aspekter ved situationer og karakterer, så disse afspejler virkelige scenarier, kan disse studier bidrage med vigtig information om forhold, der indvirker på vidners adfærd. Da deltagerne skal svare hypotetisk, som om de var en karakter i casen, kan de også distancere sig fra de beskrevne dilemmaer, hvilket mindsker risikoen for indvirkning af social ønskværdighed (Torres, 2009).

Eksperimenter, hvori der anvendes vignettes, har dog flere begrænsninger. En er, at deltagernes svar afspejler, hvad de har til hensigt at gøre i en fiktiv situation, hvilket kan være forskellige fra, hvad de ville gøre i en virkelig situation (Hershcovis et al., 2017). I en 'real-life' situation vil de forhold, som vidner vurderer krænkende handlinger ud fra, ofte være mere komplekse og følelsesladede. Vignette studier har derfor begrænset økologisk validitet (Torres, 2009). I herværende sammenhæng vil organisatoriske case- 
studier eller studier af kritiske hændelser via interviews og observationer kunne bidrage med data, som måske giver et mere realistisk indblik i de forhold, som påvirker vidners adfærd.

Selvom empirien, der støtter de to teoretiske modeller, kan kritiseres, vurderes modellerne dog at være anvendelige til udarbejdelse af en forandringsmodel, der skal styre arbejdet med at udvikle en vidneintervention. De teoretiske modeller er dog, som antydet af bl.a. Fiori et al. (2016), stadig ufuldstændige, idet de ikke giver tilstrækkeligt fyldestgørende svar på, hvilke andre forhold, der også kan indvirke på vidners adfærd. Med udgangspunkt i sekundær empiri fra mobningsforskningen gives nedenfor nogle foreløbige bud på faktorer, som også kan indgå i en forandringsmodel. Artiklen har ikke som ærinde at lave en udtømmende liste af alle relevante forhold. Der gives derfor kun eksempler på forhold ved en organisations eller gruppes kultur, som vurderes at indvirke på vidners adfærd.

\section{Indvirkning af gruppe- og organisationskultur på vidners adfoerd}

Kulturelt baserede normer vedrørende, hvad der opleves som passende adfærd, kan påvirke forekomsten af krænkende handlinger og vidners adfærd heroverfor. På nogle arbejdspladser er der en stærk humorkultur, som fx kommer til udtryk ved, at kolleger konstant driller hinanden eller kommer med nedsættende bemærkninger om hinandens arbejde (Collinson, 1993; Mortensen og Baarts, 2018). Ligeledes kan organisatoriske normer, der lægger vægt på streng disciplin, sejhed, solidaritet og efterlevelse af regler (Archer, 1999; McKay, 2013), nogle steder føre til en generel accept af aggression, som det derfor frarådes at gribe ind overfor. Herved påvirkes både vidners opfattelse af krænkelsernes alvorlighed og deres tilbøjelighed til at gribe ind. I tråd med Mortensen og Baarts' (2018) feltstudie på et dansk hospital, viste Miller og Rayners (2012) undersøgelse af britiske politibetjente, hvordan mobning var en integreret del af organisationens inklusionsproces, og at blot det $i k k e$ at deltage i den rituelle mobning kunne medføre social udstødelse.

Vidners lyst til og mulighed for at adressere krænkende adfærd vil også påvirkes af en organisations etiske infrastruktur (Einarsen et al., 2017) og dens klima for konflikthåndtering (Einarsen et al., 2016). Etisk infrastruktur refererer til formelle og uformelle systemer, som aktiverer etisk adfærd og deaktiverer uetisk adfærd, mens klima for konflikthåndtering defineres som ansattes vurderinger af en organisations procedurer for konflikthåndtering, og hvor retfærdige og forudsigelige samspilsmønstre ledere og medarbejdere imellem opleves at være i den henseende. Begge begreber relaterer sig til, eller er delaspekter af, begrebet psykosocialt sikkerhedsklima, som er politikker, praksisser og procedurer i en organisation, der er til for at beskytte medarbejdernes mentale helbred og sikkerhed (Dollard et al., 2017). En metaanalyse af 35 studier (Yang et al., 2014) fandt stærke sammenhænge mellem krænkende handlinger og medarbejderes opfattelser af arbejdspladsens politikker, procedurer og praksisser i relation til forebyggelse af krænkende handlinger. I organisationer med gode (og velimplementerede) mobbepolitikker og et godt klima for konflikthåndtering vil medarbejdere i højere grad have tillid til, at deres ledere håndterer konflikter og krænkende handlinger proaktivt og professionelt, og også opleve, at de selv risikofrit kan handle i konkrete sager (Einarsen et al., 2016). Dette gælder formodentlig især for medarbejdere, som arbejder under etiske ledere (se Ahmad, 2018; Mayer et al., 2012). 


\section{Anden fase: Udvikling af en forandringsmodel}

Med en nu erhvervet forståelse af centrale mekanismer i vidners adfærd overfor krænkende handlinger, bevæger artiklen sig videre til næste fase i udviklingen en vidneintervention. Konkret skal det teoretiske og empiriske fundament anvendes til at beskrive de veje, hvorigennem interventionen formodes at påvirke de faktorer eller mekanismer, som indvirker på vidners adfærd, og igen medfører bestemte effekter (Bartholomew og Mullen, 2011, s. 23). Der kan her med fordel udvikles en programteori, som kan anvendes til at opstille en model, fx i en matrix, over de forandringsmål, som en intervention tilstræber. Ideelt set illustrerer modellen alle de forhold, som interventionen skal adressere, og som må forandres for at interventionen er effektiv.

Det første mål for interventionen er de faktorer, som formodes at påvirke vidners adfærd. I denne fase skal derfor undersøges dels generelle faktorer, som hænger sammen med en positiv forandring i vidneadfærd, dels specifikke mekanismer, som er involveret $i$ en positiv adfærdsændring. Hvad angår generelle faktorer, kan det formodes, at særligt proximale, gruppebaserede interventioner faciliterer mere læring end én-til-én træning (Lewin, 1951), også fordi der er mulighed for social indlæring. Fx vil personer med en stærk moralsk identitet, eller en mere kompleks forståelse for krænkelsers dynamik, kunne motivere og påvirke mindre bevidste kolleger til at forstå vidners rolle og ansvar i situationer med krænkelser.

Med hensyn til specifikke mekanismer som hænger sammen med en positiv forandring i vidneadfærd, påvirkes vidners adfærd $f x$ af deres vurderinger af de krænkende handlingers alvorlighed, deres attributioner i forhold til ansvaret for at handlingerne opstår og vedvarer og deres relation til krænker og den krænkede person. Derudover påvirkes vidners adfærd også af magtforskelle, frygt for repressalier og individuelle moralske værdier. Som et eksempel på en videreudvikling af en forandringsmodel (se også Pouwelse et al., 2018), formodes vurderinger af krænkelsers alvorlighed $\mathrm{fx}$ at være relateret til vidners evne og parathed til at empatisere med den krænkede og at tage dennes perspektiv. Dette kan igen afhænge af, hvor bevidste vidner er om, hvad krænkelser og mobning er, hvordan de opstår, og hvilke sociale og psykiske konsekvenser, de kan have. Mobning kan foregå subtilt og i det skjulte (Samnani, 2013). En intervention bør derfor bidrage til øget viden og bevidsthed om krænkende handlinger og mobning, hvordan fænomenerne opstår, og vidners rolle heri. Interventioner, der beskriver de psykologiske effekter af krænkelser, vil øge sandsynligheden for, at vidner tager mobbedes perspektiv og derfor ønsker at hjælpe dem. Om vidner tager mobbedes perspektiv og hjælper, afhænger dog også af de normer vedrørende brug af krænkende handlinger, der eksisterer i en given organisatorisk kontekst. I tråd med dette kan vidners adfærd påvirkes af frygt for repressalier, hvorfor det vil være vigtigt at adressere og øge den oplevede psykologiske sikkerhed på arbejdspladsen, $f x$ ved at sætte fokus på normer for krænkende handlinger, eller ved at skabe et konstruktivt klima for konflikthåndtering og en stærk etisk infrastruktur.

\section{Tredje fase: Udvoelgelse af interventionsmetoder}

I tredje fase i Bartholomew og Mullens (2011) interventionsmodel benyttes teori og empiri til at udvælge én eller flere interventionsmetoder, samt særlige interventionsstrategier, som skal ændre de forhold, som er bestemmende for passiv og assisterende vidneadfærd. Da designet af en konkret vidneintervention vil være $i$ fokus i en senere artikel, gives der her kun eksempler på ind- 
holds- og proceselementer, som kan indgå $i$ en sådan intervention (se også Pouwelse et al., 2018). Fx peger empiri på, at vidners adfærd påvirkes af, om de kan (og vil) tage den krænkedes perspektiv. Det peger på, at der kan være god effekt $i$ at anvende interventioner, som inkluderer korte film, der foregår i en arbejdskontekst, som deltagerne kan relatere til. Det er også vigtigt, at deltagerne kan identificere sig med karaktererne i filmene, da det er en forudsætning for, at de involverer sig følelsesmæssigt (Pouwelse et al., 2018). Disse film må også kunne illustrere de psykiske konsekvenser af at være udsat for mobning (Scully og Rowe, 2009) samt beskrive, hvordan forskellige former for vidneadfærd henholdsvis kan hæmme eller fremme udviklingen af mobning. Der kan også designes interventioner bygget op omkring gruppe- og plenumdiskussioner af relevante cases, der fx er beskrevet på små kort eller plancher med illustrationer. Fælles drøftelser i mindre grupper af film og cases vil kunne øge deltagernes bevidsthed om dynamikker i udviklingen af mobning, og hvordan vidneadfærd spiller en vigtig rolle heri. Som et led i sådanne interventioner kunne der med fordel indgå træning, fx i form af rollespil, hvor deltagerne kunne øve sig på at gribe konstruktivt ind.

\section{Konklusion og perspektivering for praksis}

Hensigten med denne artikel har været at bidrage til udvikling af en teoretisk og metodisk forståelsesramme, som kan anvendes $i$ arbejdet med at designe interventioner, som aktiverer vidner til at gribe ind overfor krænkende handlinger og mobning. Ud fra Bartholomew og Mullens (2011) model over interventionsforskning beskæftigede artiklen sig med tre faser i udviklingen af en vidneintervention. Under behandlingen af den første fase blev der, med udgangspunkt i to teoretiske modeller og sekundær empiri, identificeret forhold og mekanismer, som påvirker vidners adfærd i relation til krænkende handlinger. Disse var: vurderinger af krænkelsernes alvorlighed og hvem der er ansvarlig for, at de er opstået og vedvarer, om den krænkede fortjener behandlingen, relationer og magtforhold mellem vidne, krænker og krænket, og om det at gribe ind indebærer en risiko for vidnet selv.

For yderligere at kvalificere en interventions vidensgrundlag beskrev artiklen også, hvordan vidners adfærd kan påvirkes af aspekter ved gruppers og organisationers kultur, fx i hvor høj grad krænkende handlinger accepteres, om der er en stærk eller svag etisk infrastruktur og et godt eller dårligt klima for konflikthåndtering, samt om der udøves etisk ledelse eller ej. Det siger sig selv, at der vil være andre forhold på både organisations-, gruppe- og individniveau, som også kan påvirke vidners adfærd. Hellemans et al. (2017) fandt fx, at personer med lav grad af selvkompetence (self-effica$c y$ ) rapporterede mere frygt for at gribe ind overfor krænkende handlinger. Betydning af fx gruppesammenhæng og gruppeidentitet for vidneadfærd bør også undersøges.

I behandlingen af modellens anden fase indledtes arbejdet med at udvikle en forandringsmodel, der skal beskrive, hvordan en intervention kan påvirke de forhold og mekanismer, der indvirker på vidners adfærd. Herefter blev der i den korte behandling af modellens tredje fase foreslået specifikke interventioner og interventionsmetoder, som formodes at kunne adressere forhold, som påvirker vidneadfærd. Den fjerde og femte fase i forskningsprocessen, implementering og evaluering af interventionen, blev ikke behandlet i artiklen, men skal her have et ord med på vejen.

Implementering af organisatoriske interventioner skal baseres på indledende analyser af de forhåndenværende udfordringer, ef- 
terfulgt af veldesignede interventioner hvis implementering og effekt vurderes gennem proces- og effektevalueringer (Nielsen og Noblet, 2017). Ud over at teori og empiri danner baggrund for en interventions adfærdsændrende indholds- og proceselementer, kan teori og empiri også bidrage til øget bevidsthed om, hvilke kontekstforhold der kan indvirke positivt eller negativt på dens implementering og effekt. Som både forskere og arbejdsmiljøprofessionelle vil være bevidste om, har mange interventioner begrænset effekt eller mislykkes (Aust et al., 2010). Det kan skyldes negative indvirkninger fra procesfaktorer som $\mathrm{fx}$ lavt engagement hos ledelsen, manglende planlægning og opfølgning, eller at medarbejderne anser den pågældende intervention for irrelevant (se Mikkelsen et al., 2011). I det sidste tilfælde kan der have været utilstrækkelig information om, hvorfor en intervention er implementeret, eller måske er det adresserede problem ikke erkendt. Ved implementering af interventioner rettet mod vidner til mobning, skal for- og efterarbejdet derfor prioriteres.

Udgangspunktet for denne artikel har været, at vidner spiller en vigtig rolle i forebyggelse af mobning på arbejdspladsen. På denne baggrund er der i artiklen samlet viden, som også kan bruges i andre sammenhænge. Fx kan formidling af viden om de forhold, der påvirker vidners adfærd, bruges i virksomheders forebyggende arbejde. Den beskrevne viden kan også anvendes i den terapeutiske behandling af mobbede, eller som led i et teams efterbearbejdning af en mobbesag. Formålet er ikke at fjerne det personlige og ledelsesmæssige ansvar, der kan ligge hos dem, som ikke har grebet ind overfor mobning, men at skabe en dybere forståelse for dynamikker og en fælles drøftelse af fremtidige handlemuligheder.

En af de ting, som en vidneintervention kan gøre, er at medvirke til at højne den almene moral og bevidsthed om mobningsproblematikken (Resch og Schubinski, 1996). Øget bevidsthed og oplevelse af et moralsk medansvar er sandsynligvis centrale forudsætninger for, at vidner griber ind. Men bevidsthed og moral er ikke altid nok. For hvad nytter det at være bevidst om, at man bør gribe ind, hvis ikke man tør? I et forebyggelsesperspektiv er arbejdet for at skabe eller fastholde psykologisk sikkerhed derfor afgørende. I nogle tilfælde vil det kræve en større kulturændring, som begynder ved ledelsen. Etiske ledere vil alt andet lige bidrage til at skabe psykologisk sikkerhed i en organisation. Forebyggelse af mobning handler derfor også om rekruttering og fastholdelse af etiske ledere - det sidste ved at belønne ledere, som udøver etisk ledelse.

Endelig handler forebyggelse af mobning om at prioritere det løbende arbejdsmiljøarbejde. Et dårligt arbejdsmiljø skaber forudsætninger for konflikter, normbrud, oplevet uretfærdighed og krænkende handlinger. Et godt arbejdsmiljø bidrager derimod til sunde arbejdsfællesskaber. I et sundt arbejdsfællesskab er der ikke mobning.

Archer, D. (1999). Exploring `bullying’ culture in the para-military organisation. International Journal of Manpower, 20(1/2), 94-105. doi: $10.1108 / 01437729910268687$

Aquino, K., \& Reed, A., II. (2002). The self-importance of moral identity. Journal of Personality 
and Social Psychology, 83(6), 1423-1440. doi: 10.1037/0022-3514.83.6.1423

Aust, B., Rugulies, R., Finken, A., \& Jensen, C. (2010). When workplace interventions lead to negative effects: Learning from failures. Scandinavian Journal of Public Health, 38(Suppl 3), 106-119. https://doi. org/10.1177/1403494809354362

Bartholomew, L. K., \& Mullen, P. D. (2011). Five roles for using theory and evidence in the design and testing of behavior change interventions. Journal of Public Health Dentistry, 71(Supplement 1), 20-33. doi: 10.1111/j.17527325.2011.00223.

Baumeister, R. F., Bratslavsky, E., Finkenauer, C., \& Vohs, K. D. (2001). Bad is stronger than good. Review of General psychology, 5(4), 323370, doi: 10.1037//1089-2680.5.4.32

Bjørkelo, B., Thorsen, C., D'Cruz, P. \& Mikkelsen, E. G. (2018). Whistleblowing and bullying at work: The role of leaders. In P. D'Cruz, E. Noronha, L. Keashly \& S. Tye-Williams (Eds), Handbooks of Workplace Bullying, Emotional Abuse and Harassment: Special Topics and Particular Occupations, Professions and Sectors (Vol 4). Springer. doi: 10.1007/978-981-10-51548_1-1

Bloch, C. (2013). Vidner som aktører i mobning. I C. Mossfeldt Nickelsen (Ed.), Arbejdslivets skyggesider (s. 217-236). Århus: Klim. ISBN 9788771290028

Bolger, N., Foster, M., Vinokur, A. D. \& Ng, R. (1996). Close relationships and adjustment to a life crisis: The case of breast cancer. Journal of Personality and Social Psychology, 70(2), 283-294. Bolger et al doi: https://doi. org/10.1037/0022-3514.70.2.283

Bos, A. E. R., Dijker, A. J. M., \& Koomen, W. (2007). Sex differences in emotional and behavioral responses to HIV+ individuals' expression of distress. Psychology \& Health, 22(4), 493-511. doi: 10.1080/14768320600976257

Collinson, D. L. (1988). "Engineering humour": Masculinity, jokings and conflict in shop-floor relations. Organization Studies, 9(2), 181-199. Collinson doi https://doi. org/10.1177/017084068800900203
Cooper-Thomas, H., Bentley, T. A., Catley, B. E., Gardner, D. H., O’Driscoll, M., \& Trenberth, L. (2014). The impact of bullying on observers and targets. New Zealand Journal of Human Resource Management, 14(2), 82-95.

Copeland, J. T. (1994). Prophecies of power: Motivational implications of social power for behavioral confirmation. Journal of Personality and Social Psychology, 67(2), 264-277. doi: 10.1037/0022-3514.67.2.264

D'Cruz, P., \& Noronha, E. (2011). The limits to workplace friendship: Managerialist HRM and bystander behaviour in the context of workplace bullying. Employee Relations, 33(3), 269-288. doi: 10.1108/01425451111121777

D'Cruz, P., Paull, M., Omari, M., \& Guneri-Cangarli, B. (2016). Target experiences of workplace bullying: insights from Australia, India and Turkey. Employee Relations, 38(5), 805-823. doi: 10.1108/ER-06-2015-0116

Desrumaux, P., Jeoffrion, C., Bouterfas, N., De Bosscher, S., \& Boundenghan, M. (2018). Workplace bullying: how do bystanders' emotions and the type of bullying influence their willingness to help-giving? Nordic Psychology, 259-277. doi.org/10.1080/19012276. 2018.1430610

Desrumaux, P., Machado, T., Przygodzki-Lionet, N., \& Lourel, M. (2015). Workplace bullying and victims' prosocial or antisocial behaviors: What are the effects on equity, responsibility judgments, and help giving? Journal of Human Behavior in the Social Environment, 25(6), 509521. doi: 10.1080/10911359.2014.988318

Dijker, A. J. M., \& Koomen, W. (2003). Extending Weiner's attribution-emotion model of stigmatization of ill persons. Basic and Applied Social Psychology, 25(1), 51-68. doi: 10.1207/ S15324834BASP2501 4

Dollard, M. F., Dormann, C., Tuckey, M. R. \& Escartín, J. (2017). Psychosocial safety climate (PSC) and enacted PSC for workplace bullying and psychological health problem reduction, European Journal of Work and Organizational Psychology, 26(6), 844-857. doi: 10.1080/1359432X.2017.1380626 
Dunkel-Schetter, C., Folkman, S., \& Lazarus, R. S. (1987). Correlates of social support receipt. Journal of Personality and Social Psychology, 53(1), 71-80. doi: 10.1037/0022-3514.53.1.71

Einarsen, S., Hoel, H., Zapf, D., \& Cooper, C. L. (2020). The concept of bullying and harassment at work: The European tradition. I S. Einarsen, H. Hoel, D. Zapf \& C. L. Cooper (Eds.), Bullying and Harassment in the Workplace: Theory, Research, and Practice (354). Boca Raton FL: Taylor \& Francis. doi: 10.1201/9780429462528-2

Einarsen, S., Skogstad, A., Rørvik, E., Lande, Å. B., $\&$ Nielsen, M. B. (2016). Climate for conflict management, exposure to workplace bullying and work engagement: a moderated mediation analysis. The International Journal of Human Resource Management, 1-22. doi: 10.1080/09585192.2016.1164216

Einarsen, K., Mykletun, R. J., Einarsen, S. V., Skogstad, A., \& Salin, D. (2017). Ethical infrastructure and successful handling of workplace bullying. Nordic Journal of Working Life Studies, 7(1). doi: 10.18291/njwls.v7i1.81398

Fiori, M., Krings, F., Kleinlogel, E. \& Reich, T. (2016). Whose side are you on? Exploring the role of perspective taking on third-party's reactions to workplace deviance. Basic and Applied Social Psychology, 38(6), 318-336. doi: 10.1080/01973533.2016.1215984

Folger, R. (2001). Fairness as deonance. I S. W. Gilliland, D. D. Steiner \& D. P. Skarlicki (Eds.), Research in Social Issues in Management (3-31). Charlotte, NC: Information Age.

Gardner, D., Bentley, T., Catley, B., Cooper-Thomas, H., O' Driscoll, M., \& Trenberth, L. (2013). Ethnicity, workplace bullying, social support and psychological strain in Aotearoa/ New Zealand. New Zealand Journal of Psychology, 42(1), 123-130.

Goffman, E. (1963). Stigma: Notes on the management of spoiled identity. Englewood Cliffs, NJ: Prentice-Hall.

Hellemans, C., Dal Cason, D., \& Casini, A. (2017). Bystander helping behavior in response to workplace bullying. Swiss Journal of Psychology, 76(4), 135-144. doi: 10.1024/1421-0185/ a000200
Hershcovis, M. S. \& Bhatnagar, N. (2017). When fellow customers behave badly: witness reactions to employee mistreatment by customers. Journal of Applied Psychology, 102(11), 15281544. doi: https://doi.org/10.1037/apl0000249

Hershcovis, M. S., Neville, L., Reich, T. C., Christie, A. M., Cortina, L. M., \& Shan, J. V. (2017). Witnessing wrongdoing: The effects of observer power on incivility intervention in the workplace. Organizational Behavior \& Human Decision Processes, 142, 45-57. doi: 10.1016/j. obhdp.2017.07.006

Hogh, A., Conway, P. M., \& Mikkelsen, E. G. (2017). Prevalence and risk factors for workplace bullying. In P. Sturmey (Ed.), The Wiley Handbook of Violence and Aggression (Vol. 3. Societal Interventions): John Wiley \& Sons Publisher. ISBN 9781119057574

Keltner, D., Gruenfeld, D. H., \& Anderson, C. (2003). Power, approach, and inhibition. Psychological Review, 110, 265-284. doi: 10.1037/0033-295x.110.2.265

Kiewitz, C., Restubog, S. L. D., Shoss, M. K., Garcia, P. R. J. M., \& Tang, R. L. (2016). Suffering in silence: Investigating the role of fear in the relationship between abusive supervision and defensive silence. Journal of Applied Psychology, 101(5), 731-742. doi:10.1037/apl0000074

Kirby, R., og Corzine, J. (1981) The contagion of stigma: Fieldwork among deviants. Qual Sociol, 4, 3-20 https://doi.org/10.1007/BF00987041

Lansbury, L. (2014). The development, measurement and implementation of a bystander intervention strategy: A field study on workplace verbal bullying in a large UK organisation (Ph.d. afhandling fra University of Portsmouth, UK). Downloaded fra https://core.ac.uk/display/77050198

Lewin, K. (1951). Field theory in social science: selected theoretical papers. Oxford, England: Harpers.

Lewis, S. E., \& Orford, J. (2005). Women's experiences of workplace bullying: changes in social relationships. Journal of Community \& Applied Social Psychology, 15(1), 29-47. doi: 10.1002/ casp. 807

Lutgen-Sandvik, P., \& Fletcher, C. V. (2013). Conflict motivations and tactics of targets, bystanders, and bullies: A thrice-told tale of 
workplace bullying. In J. Oetzel \& S. Ting-Toomey (Eds.), The SAGE handbook of conflict communication (349-377). Thousand Oaks, CA: SAGE Publications, Inc. ISBN: 9781412987790

Lutgen-Sandvik, P. \& McDermott, V. (2011) Making sense of supervisory bullying: Perceived powerlessness, empowered possibilities, Southern Communication Journal, 76(4), 342368, doi: 10.1080/10417941003725307

Mayer, D. M., Aquino, K., Greenbaum, R. L. \& Kuenzi, M. (2012). Who displays ethical leadership, and why does it matter? An examination of antecedents and consequences of ethical leadership. Academy of Management Journal, 55(1), 151-171. http://dx.doi. org/10.5465/amj.2008.0276

McKay, R. B. (2014). Confronting workplace bullying: Agency and structure in the Royal Canadian Mounted Police. Administration \& Society, 46(5), 548-572. doi: $10.1177 / 0095399713509245$

Meng, A., Borg, V. \& Clausen, T. (2019). Enhancing the social capital in industrial workplaces: Developing workplace interventions using intervention mapping. Evaluation and Program Planning, 72, 227-236. doi:10.1016/j. evalprogplan.2018.11.007

Mikkelsen, E. G. (2007). Mobning - et fænomen eller flere? Kap. 1 i D. Perlt \& K. Pedersen, (eds.), Den stille epidemi - om mobning på arbejdspladsen (9-35). København: SUS. ISBN 978-87-92182-00-5

Mikkelsen, E. G., Hansen, Å. M., Persson, R., Fosgrau, M. \& Høgh, A. (2020). Individual consequences of being exposed to workplace bullying. I S. Einarsen, H. Hoel, Zapf, D. \& Cooper, C. L., Bullying and Harassment in the Workplace. Theory, Research and Practice (3rd ed.) (163-208). Boca Raton, FL; CRC Press. Taylor and Francis Group.doi: 10.1201/9780429462528-2

Mikkelsen, E. G., Hogh, A., \& Puggaard, L. (2011). Prevention of bullying and conflicts at work: Process factors influencing the implementation and effects of interventions. International Journal of Workplace Health Management, 4(1), 84-100. doi:10.1108/17538351111118617

Miller, H., \& Rayner, C. (2012). The form and function of 'bullying' behaviors in a strong occupational culture: Bullying in a U.K. police service. Group and Organization Management, 37(3), 347-375 https://doi. org/10.1177/1059601112449476

Mortensen, M., \& Baarts, C. A. (2018). Killing ourselves with laughter...mapping the interplay of organizational teasing and workplace bullying in hospital work life. Qualitative Research in Organizations and Management. 13(1), 10-31. https://doi.org/10.1108/QROM-10-2016-142 Mulder, R., Bos, A. E., Pouwelse, M., \& van Dam, K. (2017). Workplace mobbing: How the victim's coping behavior influences bystander responses. Journal of Social Psychology, 157(1), 16-29. doi: 10.1080/00224545.2016.1152213

Mulder, R., Pouwelse, M., Lodewijkx, H., \& Bolman, C. (2014). Workplace mobbing and bystanders' helping behaviour towards victims: The role of gender, perceived responsibility and anticipated stigma by association. International Journal of Psychology, 49(4), 304-312. doi: 10.1002/ijop.12018

Mulder, R., Pouwelse, M., Lodewijkx, H., Bos, A. E. R., \& van Dam, K. (2016). Predictors of antisocial and prosocial behaviour of bystanders in workplace mobbing. Journal of Community \& Applied Social Psychology, 26(3), 207-220. doi: 10.1002/casp.2244

Neuman, J. H., \& Baron, R. A. (2011). Social antecedents of bullying: A social interactionist perspective. In S. Einarsen, H. Hoel, D. Zapf \& C. L. Cooper (Eds.), Bullying and harassment in the workplace: developments in theory, research, and practice (201-226). Boca Raton FL: Taylor \& Francis. Neuman og Baron ISBN: 0-203-16466-0

NFA (Det Nationale Forskningscenter for Arbejdsmiljø) (2018). Fakta om Arbejdsmiljø og Helbred 2018. København: NFA, 2018. Datadokumentation https://arbejdsmiljodata. nfa.dk/

Nielsen, K. \& Noblet, A. (2017). Organizational interventions: Where we are and where we go from here? I K. Nielsen \& A. Noblet: Organizational interventions for health and well-being. A handbook for evidence-based practice (68-86). London: Routlegde. ISBN 9781138221420 
Niven, K., Ng, K. \& Hoel, H. (2020). The bystanders of workplace bullying. I S. Einarsen, $\mathrm{H}$. Hoel, Zapf, D. \& Cooper, C. L., Bullying and Harassment in the Workplace. Theory, Research and Practice (3rd ed.), 285-409. Boca Raton, FL; CRC Press. Taylor and Francis Group.DOI: 10.1201/9780429462528-2

O'Donnell, S., MacIntosh, J. and Wuest, J. (2010) A theoretical understanding of sickness absence among women who have experienced workplace bullying. Qualitative Health Research, 20(4). doi:10.1177/1049732310361242 20147503

O'Reilly, J., \& Aquino, K. (2011). A model of third parties' morally motivated responses to mistreatment in organizations. Academy of Management Review, 36(3), 526-543. doi: 10.5465/amr.2011.61031810

Paull, M., Omari, M., \& Standen, P. (2012). When is a bystander not a bystander? A typology of the roles of bystanders in workplace bullying. Asia Pacific Journal of Human Resources, 50(3), 351-366. doi: 10.1111/j.17447941.2012.00027.x

Persson, R., Mikkelsen, E. G. \& Hogh, A. (2018). The role of personality in workplace bullying research. In P. D'Cruz, E. Noronha, E. Baillien, B. Catley, K. Harlos, A. Hogh \& E. G. Mikkelsen (Eds), Handbooks of Workplace Bullying, Emotional Abuse and Harassment: Pathways of Job-related Negative Behaviour (Vol 2). Singapore: Springer. doi: 10.1007/978-98110-6173-8_4-1

Pouwelse, M., Mulder, R. \& Mikkelsen, E. G. (2018). The role of bystanders in workplace bullying - an overview of theories and empirical research. In P. D'Cruz, E. Noronha, E. Baillien, B. Catley, K. Harlos, A. Hogh \& E. G. Mikkelsen (Eds), Handbooks of Workplace Bullying, Emotional Abuse and Harassment: Pathways of Job-related Negative Behaviour (Vol 2). Springer. https://doi.org/10.1007/978-98110-6173-8_14-

Resch, M. \& Schubinski, M. (1996). Mobbing-prevention and management in organizations. European Journal of Work and Organizational Psychology, 5(2), 295-307. https://doi. org/10.1080/13594329608414860
Samnani, A. K. (2013). "Is this bullying?" Understanding target and witness reactions. Journal of Managerial Psychology, 28(3), 290-305. doi: doi:10.1108/02683941311321196

Schwarzer, R., \& Weiner, B. (1991). Stigma controllability and coping as predictors of emotions and social support. Journal of Social and Personal Relationships, 8, 133-140. doi: 10.1177/0265407591081007

Scully, M., \& Rowe, M. (2009). Bystander training within organizations. Journal of the International Ombudsman Association, 2(1), 89-95.

Shallcross, L., Ramsay, S., \& Barker, M. (2013). Severe workplace conflict: The experience of mobbing. Negotiation and Conflict Management Research, 6(3), 191-213. doi: 10.1111/ ncmr.12011

Skarlicki, D. P. \& R. Folger (1997). Retaliation in the workplace: The roles of distributive, procedural and interactional justice. J. Appl. Psych, 83, 434-443. doi:

10.1037/0021-9010.82.3.434

Skarlicki, D. P., \& Rupp, D. E. (2010). Dual processing and organizational justice: The role of rational versus experiential processing in third-party reactions to workplace mistreatment. Journal of Applied Psychology, 95(5), 944-952. doi: 10.1037/a0020468

Twemlow, S. W., Fonagy, P., \& Sacco, F. C. (2004). The role of the bystander in the social architecture of bullying and violence in schools and communities. Annals New York Academy of Sciences, 1036, 215-232. doi: 10.1196/annals.1330.014

Tye-Williams, S., \& Krone, K. J. (2015). Chaos, reports, and quests: Narrative agency and co-workers in stories of workplace bullying. Management Communication Quarterly, 29(1), 3-27. doi: 10.1177/0893318914552029

Torres, S. (2009). Vignette methodology and culture-relevance: Lessons learned through a project on successful aging with Iranian immigrants to Sweden. J Cross Cult Gerontol 24(1), 93-114 doi 10.1007/s10823-009-9095-9

Van Heugten, K. (2011). Theorizing active bystanders as change agents in workplace bullying of social workers. Families in Society: The Journal 
of Contemporary Social Services, 92(2), 219-224. doi: 10.1606/1044-3894.4090

Weiner, B., Perry, R. P., \& Magnusson, J. (1988). An attributional analysis of reactions to stigmas. Journal of Personality and Social Psychology, 55(5), 738-748. doi: 10.1037/00223514.55.5.738

Wu, S. H. and Wu, C. C. (2019). Bullying bystander reactions: A case study in the Taiwanese workplace. Asia Pacific Journal of Human Resources, 57(2), 191-207.

Yang, L.Q., Caughlin, D. E., Gazica, M. W., Truxi1lo, D. M., Spector, P. E. (2014). Workplace mistreatment climate and potential employee and organizational outcomes: A meta-analytic review from the target's perspective. Journal of Occupational Health Psychology, 19(3), 315335. doi: 10.1037/a0036905

Eva Gemzøe Mikkelsen, erhvervspsykolog, lektor i arbejds- og organisationspsykologi, ph.d Syddansk Universitet

e-mail: egmikkelsen@health.sdu.dk 